\title{
ORGANISASI PEMBELAJARAN, KOMPETENSI DAN KINERJA KARYAWAN BANK XXX DI JAKARTA
}

\author{
Thea Herawati R. ${ }^{1}$, Purwanto ${ }^{2}$ \\ ${ }^{1}$ Jurusan Ekonomi Manajemen, Universitas Tarumanagara Jakarta \\ Email:thearahardjo@gmail.com \\ ${ }^{2}$ Jurusan Ekonomi Manajemen, Universitas Tarumanagara Jakarta \\ Email:purwantoseputro@yahoo.com
}

\begin{abstract}
ABSTRAK
This study aimed to determine empirically learning organization have affect to competence, competence have significant affects to performance, learning organization through competence have significant affect to performance. The method used in sampling was simple random sampling, a total of 200 employee at Bank "XXX" in Jakarta The data analysis technique used is Structural Equation Modeling (SEM), using by LISREL versi 8.8 are need to test the hypothesis. The results showed, learning organization give effect competence, competence give effect performance, learning organization through competence give effect performance which means that the research hypothesis tested.

Through these results can be material for the attention of Bank "XXX" to keep improving the learning organization, competence heve affect the performance of the business, because through good performance can affect the competitive advantage for Bank $X X X$ " in running the business.
\end{abstract}

Keywords: learning organization, competence, performance, SEM

\section{PENDAHULUAN}

Dewasa ini persaingan bisnis semakin kondusif, baik pada sektor industri maupun jasa, menghadapi kondisi persaingan secara nasional maupun Internasional. Setiap perusahaan perlu meningkatkan kemampuan yang dimiliki,agar memilki daya saing untuk menghadapi persaingan yang semakin ketat. Senge (1999), mengemukakan saat ini dunia sedang berada di era revolusi informasi, yaitu era dimana pengetahuan berhasil diaplikasikan pada pengetahuan itu sendiri. Suatu organisasi perlu menunjang era revolusi informasi dengan menyeimbangkan kompetensi karyawannya, secara seimbang dan berkelanjutan. Ilmu pengetahuan yang dimiliki anggota dari organisasi adalah kunci sukses untuk meningkatkan kompetensi dalam mengelola organisasi. Holton(2001) menyebutkan organisasi sebagai sekelompok orang yang bekerja secara terkoordinasi untuk mencapai tujuan bersama. Bagi suatu organisasi, orang merupakan sumber utama adanya pengetahuan dan kemampuan yang perlu untuk didistribusikan, dipertukarkan, dan disempurnakan melalui interaksi antar anggota, dalam mencapai kompetensi secara lebih baik dan kinerja organisasipun dapat ditingkatkan.. Lopez et al. (2005) adalah organisasi pembelajaran sebagai suatu proses dinamis dalam menciptakan, mengambil, dan mengintegrasikan pengetahuan untuk mengembangkan sumber daya dan kapabilitas dalam memberikan kontribusi pada peningkatan kompetensi seorang karyawan dan pada akhirya kinerja menjadi yang lebih baik.

Pada dasarnya perbankan merupakan organisasi (badan usaha) yang digerakkan oleh sumber daya manusia untuk mencapai suatu tujuan. Perbankan membutuhkan sumber daya manusia (SDM) yang memilki kompetensi dan kinerja yang tinggi. Boydell dan Leary (1996) serta Chaston dan Badger (1999) menggunakan dan menguji model pembelajaran organisasi,Dalam mencapai tujuan tersebut, organisasi pegawai Bank XXX di beberapa kantor cabang haruslah memiliki komitmen serta berkeinginan melakukan pembelajaran secara terus menerus. Setiap individu dalam suatu organisasi harus berubah,belajar, dan tumbuh lebih cepat dibandingkan masa lalu. Kemampuan organisasi dalam merespon perubahan harus lebih baik, kondisi ini menjadi bekal untuk menghadapi persaingan di era informasi ini. Selanjutnya organisasi tidak 
hanya harus menyesuaikan dengan perubahan yang sedang terjadi saat ini saja, tetapi juga dituntut untuk mampu mengembangkan kapabilitas unik yang memungkinkan organisasi dan individu merespon potensi perubahan-perubahan di masa datang. Kinerja tugas dan kinerja kontekstual pada perilaku karyawan secara langsung akan memberikan perubahan dalam suatu organisasi (Borman dan Motowidlo, 1997; Werner, 2000). Perilaku ini secara langsung berhubungan dengan sistem reward organisasi formal. Kinerja pada dasarnya merupakan faktor kunci untuk mengembangkan suatu organisasi secara efektif dan efesien, karena adanya kebijakan atau program yang lebih baik atas sumber daya manusia yang ada dalam organisasi. Untuk itu peneliti tertarik melakukan penelitian pada organisasi perbankan yaitu Bank XXX.

Perumusan Masalah

Beberapa hal yang menjadi permasalahan penelitian pada Bank XXX adalah:

1. Apakah organisasi belajar dan komitmen secara bersama-sama dan terpisah memiliki pengaruh terhadap kompetensi

2. Apakah Organisasi pembelajaran dan komitmen melalui kompetensi berpengaruh terhadap kinerja

3. Apakah organisasi pembelajaran melalui kompetensi memiliki pengaruh terhadap kinerja

4. Apakah komitmen melalui kompetensi memiliki pengaruh terhadap kinerja

5.Apakah kompetensi berpengaruh pada kinerja pembelajaran yang dilakukan dapat meningkatkan kompetensi berpengaruh secara langsung pada peningkataan kinerja karyawan itu sendiri. Untuk itu ke-tiga variable tersebut dapat dibuat suatu model sebagai berikut.

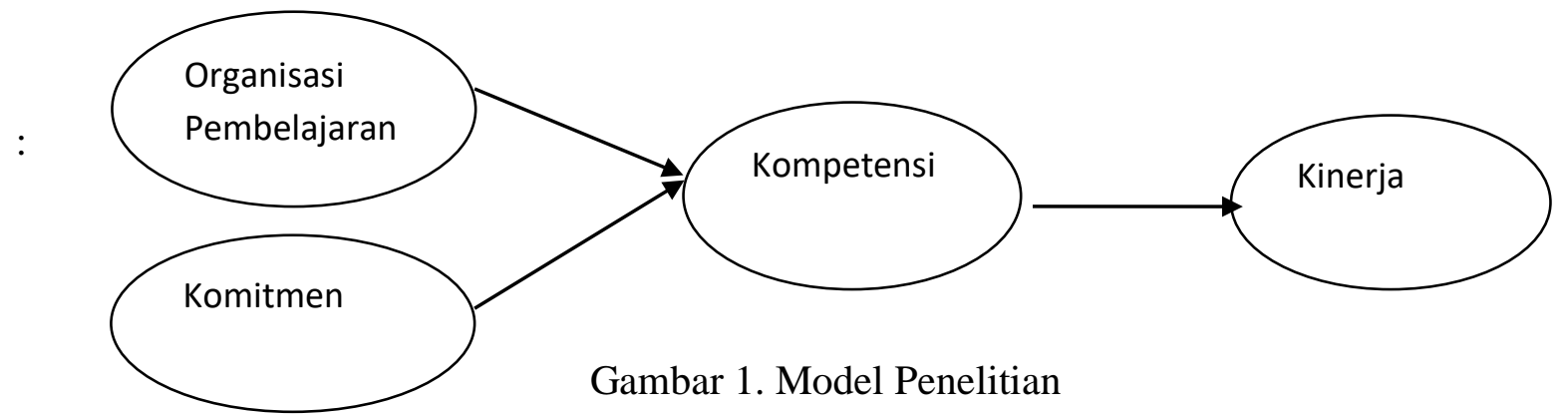

\section{Hipotesis Penelitian}

Berdasarkan model penelitian maka hipotesis yang diajukan adalah sebagai berikut:

H1: Apakah organisasi belajar dan komitmen secara bersama-sama dan terpisah memiliki pengaruh terhadap kompetensi

H2. Apakah Organisasi pembelajaran dan komitmen melalui kompetensi berpengaruh terhadap kinerja

H3. Apakah organisasi pembelajaran melalui kompetensi memiliki pengaruh terhadap kinerja

H4. Apakah komitmen melalui kompetensi memiliki pengaruh terhadap kinerja

H5. Apakah kompetensi berpengaruh pada kinerja

\section{METODE PENELITIAN}

Pada penelitian ini menggunakan sampel dengan metode Probability Sampling, adalah teknik acak sederhana, pengambilan sampel yang memberi peluang / kesempatan yang sama bagi setiap unsur atau anggota populasi untuk dipilih menjadi sampel. Jumlah sampel sebanyak 200 karyawan dirasakan telah memenuhi prinsip keterwakilan, hal ini sesuai dengan tuntutan analisis Structural Equation Modeling (SEM ) yang digunakan dalam penelitian ini yaitu 200 (Boomsma,1987 dalam Aebuckle,1997). Dengan asumsi bahwa tiap-tiap cabang bank XXX dapat terwakili. 
Khandekar dan Sharma (2006) menggunakan 9 (sembilan) item untuk mengukur pembelajaran yang berkaitan dengan aktivitas SDM, yaitu: strategi sumber daya manusia, pelatihan dan pembelajaran, penilaian kinerja, imbalan dan insentif, kondisi yang mendukung, tim kerja, penciptaan pengetahuan, kualitas manajemen, dan fleksibilitas. Watkins dan Senge (1990) dalam bukunya The Fifth Discipline: The Art dan Practice of the Learning Organization, membangun lima disiplin kunci dari pembelajaran organisasi. Menurut Sange lima disiplin tersebut yaitu system thinking, mental models, personal mastery, team learning dan building shared vision merupakan"komponen teknologis" atau dimensi yang sangat penting yang diperlukan dalam membangun pembelajaran organisasi. Menurut Marquardt (1996) untuk mewujudkan proses pembelajaran organisasi ada enam dimensi yang diperlukan yaitu system berpikir, model mental, keahlian personal, kerjasama tim, membagi visi bersama, dan dialog ini yang menjadi acuan peneliti dalam melakukan pengukuran terhadap karyawan bank XXX. Pada variabel Komitmen Organisasi, Model Pengukuran Komitmen Organisasi terdiri dari beberapa komponen yaitu komitmen afektif, komitmen kontinuan, komitmen normative, mengacu pada pendapat Allen dan Meyer (1997). Variabel Kompetensi memasukkan pengetahuan dan keahlian perusahaan dan diakumulasikan melalui proses pembelajaran berkelanjutan (Prahalad dan Hamel). Mizhael Zwell (2000) memberikan lima kategori kompetensi, yang terdiri dari task achievement, relationship, personal attribute, managerial, dan leadership, merupakan acuan yang pada penelitian ini. Untuk Variabel

Y (Kinerja pegawai), pertanyaan ditujukan bukan kepada pegawai tetapi pada 1 orang manajer HRD yang berwenang menilai kinerja pegawai yang menjadi sampel.Untuk variabel kinerja data diperoleh dari hasil wawancara kepada pihak bank dengan standar kinerja karyawan yang sudah ditetapkan atau merupakan kebijakan pihak bank XXX .

Uji validitas dalam penelitian ini dilakukan melalui proses CFA (Confirmatory factor analysis). Penilaian validitas dari CFA ditentukan dengan melihat nilai loading factor setiap indikator. Loading factor adalah cara mengidentifikasi dimensi suatu struktur dan kemudian menentukan sampai seberapa jauh setiap variabel dapat dijelaskan oleh setiap dimensi (Narbuko dan Achmadi 2005 Analisis validitas, terdapat beberapa kriteria penilaian yang harus dipenuhi pada uji validitas menggunakan LISREL, yaitu: nilai t-value dan standardized loading factor $(\lambda)$ dari variabel teramati $\geq 1.96$ dan Standardized loading factor dari variabel teramati dalam model memiliki nilai cut off $\geq 0.5$ atau $\geq 0.7$ (Hair, et al., 2006).

Analisis reliabilitas, pada measurement model dilakukan dengan menghitung nilai construct reliability dan variance extracted dari nilai-nilai standardized loading factors dan error variances. Reliabilitas model pengukuran melalui perhitungan Construct Reliability (CR) dan Variance Extracted (VE) dapat . dikatakan reliabel apabila nilai CR $\geq 0,70$ dan VE $\geq 0,5$ (Hair, et al., 2006).

Teknik analisis digunakan untuk menginterpretasikan dan menganalisis data. Sesuai dengan model multidimensi dan berjenjang yang sedang dikembangkan dalam penelitian ini alat analisis data yang dipakai adalah Structural Equation Model (SEM),yangdioperasikan rnelalui pogram LISREL versi 8.8

\section{HASIL PENELITIAN DAN PEMBAHASAN} Deskripsi subyek dan Object penelitian

Dalam deskripsi subyek penelitian ini akan diuraikan karakteristik karyawan ditinjau dari jenis kelamin, usia, pendidikan dan lama bekerja pada bank XXX, dari 200 responden yang diambil sebagai sampel penelitian. 
Deskripsi obyek penelitian berisi tanggapan responden atas kelompok pernyataan pada variabel penelitian yang terdiri atas: organisasi pembelajaran, kompetensi dan kinerja. Dengan menggunakan SPSS versi 13 statistik deskriptif menjabarkan mengenai jawaban responden dalam bentuk nilai rata-rata dan standar deviasi dari masing - masing variabel.

Nilai mean $(\bar{x})$ untuk setiap butir pernyataan, menunjukkan bahwa pada umumnya para responden memberikan pernyataan pada point 7 , secara interval mendekati 10 yang bergerak kearah sangat setuju.

\section{Confimatory Factor Analysis}

Tahap pertama yang dapat dilakukan dalam pendekatan ini adalah merespesifikasi sebuah model hybrid sebagai sebuah model CFA (Confimatory Factor Analysis). Model CFA ini merupakan model pengukuran yang memodelkan hubungan antara variabel - variabel laten dengan variabel teramati (observed/measured variable). Hubungan tersebut bersifat relektif, dimana variabelvariabel teramati merupakan refleksi dari variabel terkait. Lazimnya dalam structural equation modelling (SEM) hubungan ini bersifat con-generic, yaitu satu variabel teramati hanya mengukur atau merefleksikan sebuah variabel.

Model CFA ini digunakan untuk mengukur kesesuaiannya terhadap data, Hasil akhir CFA diperoleh melalui uji kecocokan keseluruhan model, analisis validitas dan reliabilitas model. Salah satu cara yang dapat dilakukan adalah dengan model trimming, dimana naalisis validitas model pengukuran dilakukan dengan memeriksa (a) apakah $t$-value dari standardized loading factor $(\lambda)$ dari variabel- variabel teramati dalam model ada yang $<1,96$. Selanjutnya (b) standardized loading factor $(\lambda)$ dari variabel-variabel teramati dalam model $\geq 0,07$ atau jika kita pilih saran Igbaria et al (1997) dalam Wijanto, $2008 \geq 0,50$. Jika ada variabel yang tidak memunih kedua syarat tersebut akan dihilangkan dari model. Proses penilaian model CFA (Confirmatory Factor Analysis) ini akan diaplikasikan kepada 3 variabel penelitian yang akan dijelaskan secara lebih rinci sebagai berikut:

\section{Personal Mastery}

Variabel laten Personal Masteryterdiri dari empat variabel teramati, seperti yang terlihat dalam gambar dibawah ini:

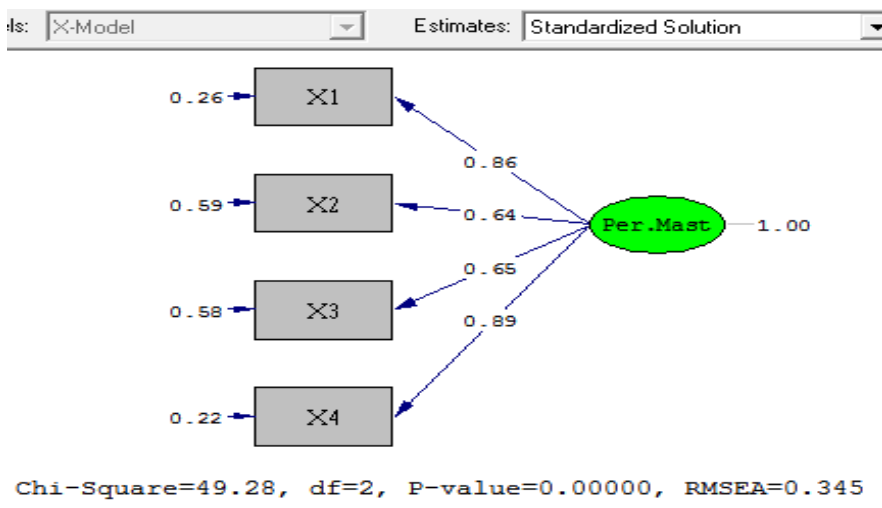

Gambar 2. Personal Mastery

Variabel dikatakan mempunyai validitas yang baik terhadap konstruk atau variabel latennya, jika dan standardizes factor loading (SLF) $\geq 0,70$ atau $\geq 0,50$. Berdasarkan nilai nilai standardizes factor loading semua variabel nilainya di atas 0,50. Hal ini menunjukkan bahwa semua variabel teramati X1 - X4 dapat dimasukkan ke dalam model. 


\section{Shared Vision}

Variabel laten Shared Visionterdiri dari enam variabel teramati, seperti yang terlihat dalam gambar dibawah ini:

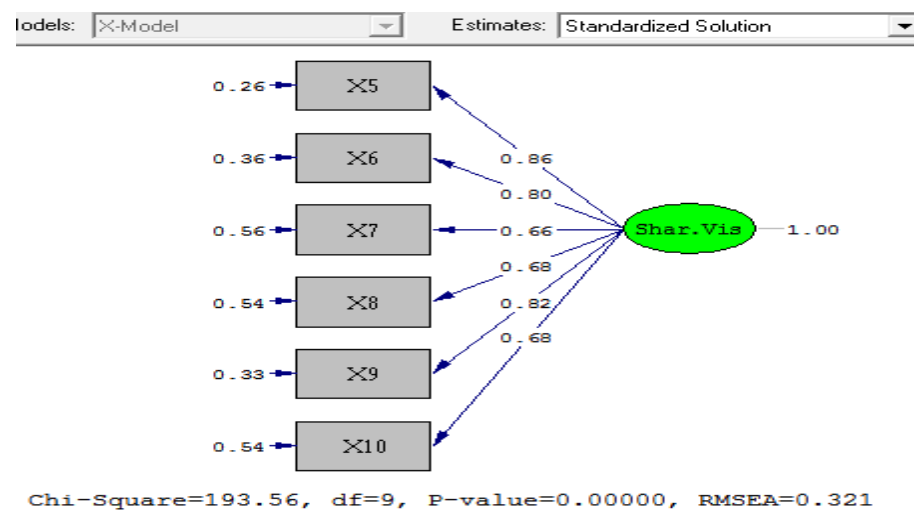

Gambar 3. Shared Vision

Variabel dikatakan mempunyai validitas yang baik terhadap konstruk atau variabel latennya, jika dan standardizes factor loading (SLF) $\geq 0,70$ atau $\geq 0,50$. Berdasarkan nilai nilai standardizes factor loading semua variabel nilainya di atas 0,50. Hal ini menunjukkan bahwa semua variabel teramati X5 - X10 dapat dimasukkan ke dalam model.

\section{Mental Model}

Variabel laten Mental Modelterdiri dari lima variabel teramati, seperti yang terlihat dalam gambar dibawah ini:

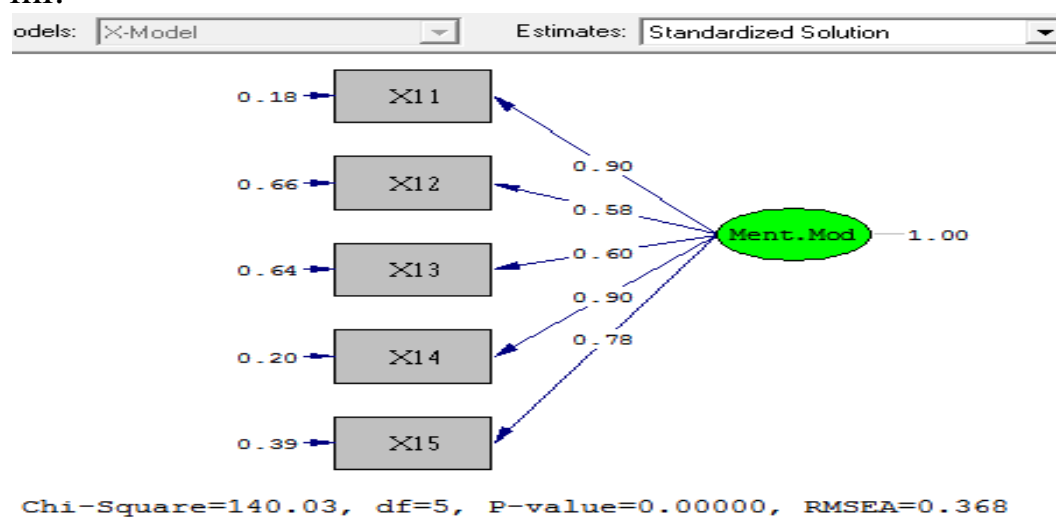

Gambar 4. Mental Model

Variabel dikatakan mempunyai validitas yang baik terhadap konstruk atau variabel latennya, jika dan standardizes factor loading (SLF) $\geq 0,70$ atau $\geq 0,50$. Berdasarkan nilai-nilai standardizes factor loading semua variabel teramati nilainya $>0,50$. Hal ini menunjukkan semua variabel teramati X11 - X15 dapat dimasukkan ke dalam model.

\section{System Thingking}

Variabel laten System Thingking terdiri dari enam variabel teramati, seperti yang terlihat dalam gambar dibawah ini: 


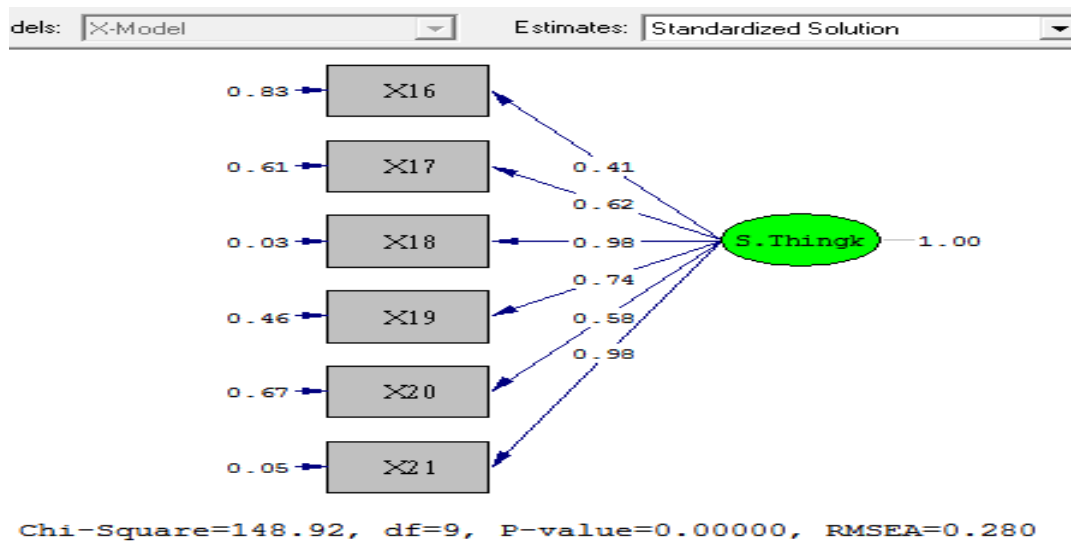

Gambar 5. System Thingking

Variabel dikatakan mempunyai validitas yang baik terhadap konstruk atau variabel latennya, jika dan standardizes factor loading (SLF) $\geq 0,70$ atau $\geq 0,50$. Berdasarkan nilai-nilai standardizes factor loading terdapat variabel teramati yang nilainya $<0,50$ yaitu X16 dengan nilai 0,41 . Hal ini menunjukkan variabel teramati X16 tidak dapat dimasukkan ke dalam model.

\section{Team Learning}

Variabel laten Team Learning terdiri dari enam variabel teramati, seperti yang terlihat dalam gambar dibawah ini:

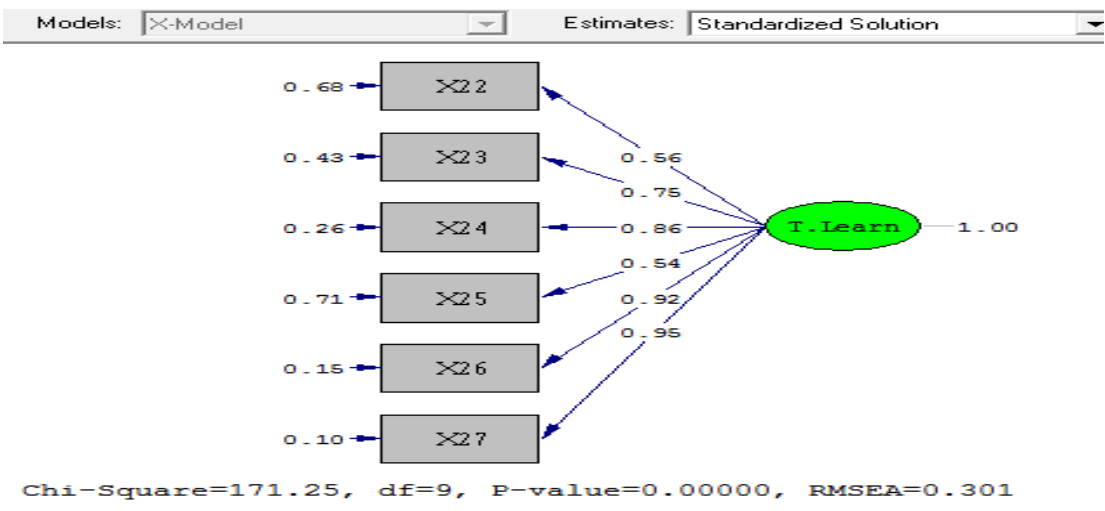

Gambar 6. Team Learning

Variabel dikatakan mempunyai validitas yang baik terhadap konstruk atau variabel latennya, jika dan standardizes factor loading (SLF) $\geq 0,70$ atau $\geq 0,50$. Berdasarkan nilai nilai standardizes factor loading semua variabel nilainya di atas 0,50. Hal ini menunjukkan bahwa semua variabel teramati X22 - X27 dapat dimasukkan ke dalam model.

\section{Afektif}

Variabel laten Afektif terdiri dari tiga variabel teramati, seperti yang terlihat dalam gambar dibawah ini: 


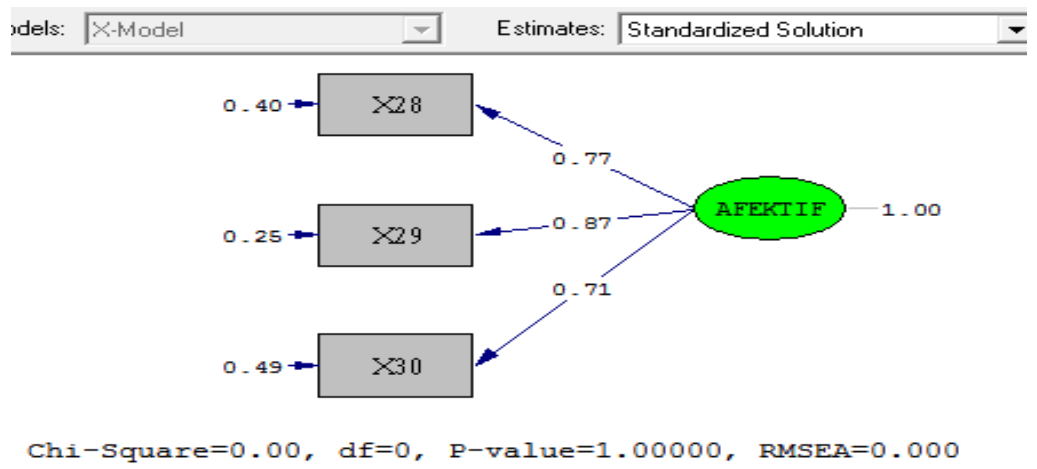

Gambar 7. Afektif

Variabel dikatakan mempunyai validitas yang baik terhadap konstruk atau variabel latennya, jika dan standardizes factor loading (SLF) $\geq 0,70$ atau $\geq 0,50$. Berdasarkan nilai nilai standardizes factor loading semua variabel nilainya di atas 0,50 . Hal ini menunjukkan bahwa semua variabel teramati X28 - X30 dapat dimasukkan ke dalam model.

\section{Continuance}

Variabel laten Continuance terdiri dari tiga variabel teramati, seperti yang terlihat dalam gambar dibawah ini:

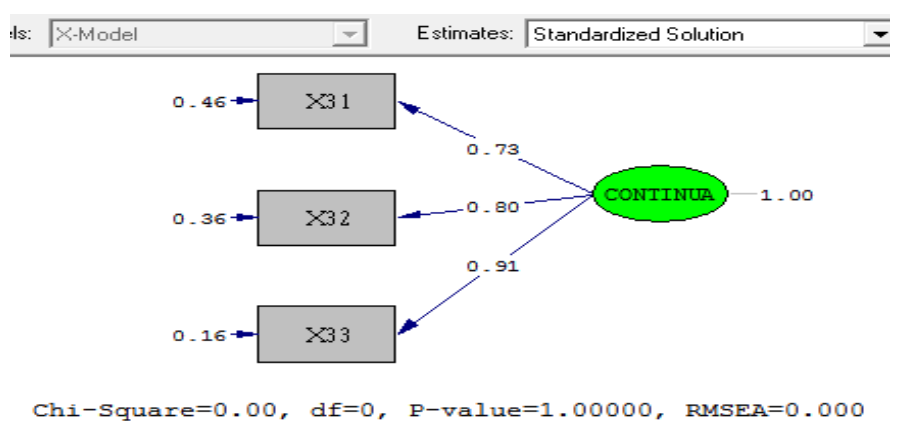

Gambar 8. Continuance

Variabel dikatakan mempunyai validitas yang baik terhadap konstruk atau variabel latennya, jika dan standardizes factor loading (SLF) $\geq 0,70$ atau $\geq 0,50$. Berdasarkan nilai nilai standardizes factor loading semua variabel nilainya di atas 0,50 . Hal ini menunjukkan bahwa semua variabel teramati X31 - X33 dapat dimasukkan ke dalam model.

\section{Normatif}

Variabel laten Normatif terdiri dari dua variabel teramati, seperti yang terlihat dalam gambar dibawah ini:

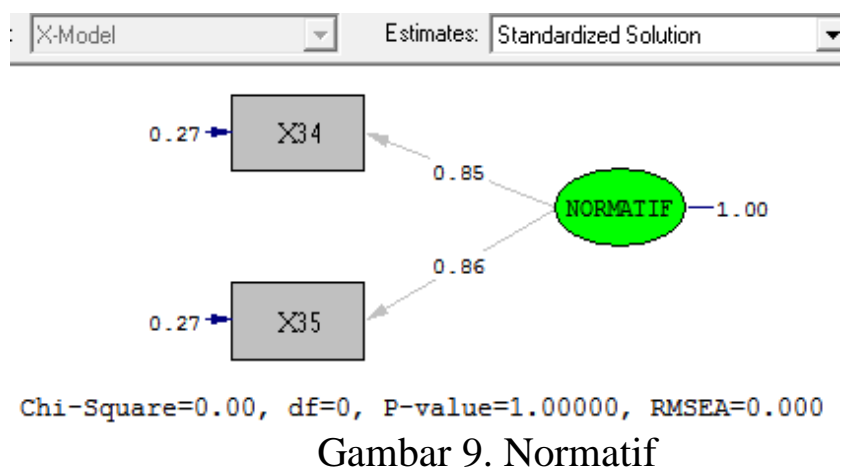


Variabel dikatakan mempunyai validitas yang baik terhadap konstruk atau variabel latennya, jika dan standardizes factor loading (SLF) $\geq 0,70$ atau $\geq 0,50$. Berdasarkan nilai nilai standardizes factor loading semua variabel nilainya di atas 0,50 . Hal ini menunjukkan bahwa semua variabel teramati X34 dan X35 dapat dimasukkan ke dalam model.

\section{Motives}

Variabel laten motivesterdiri dari lima variabel teramati, seperti yang terlihat dalam gambar dibawah ini:

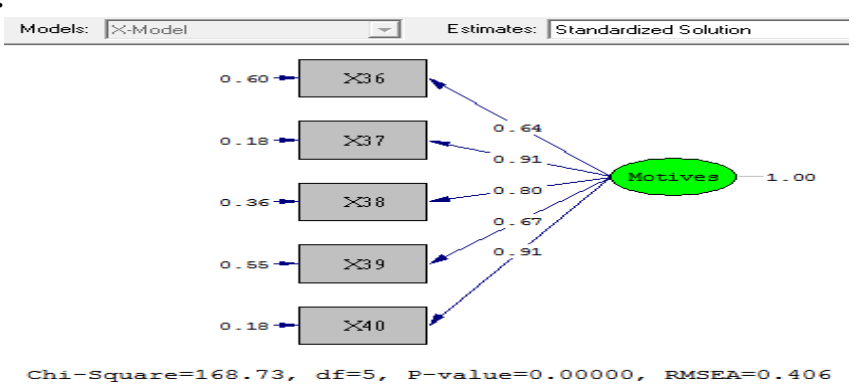

Gambar 10. Motives

Variabel dikatakan mempunyai validitas yang baik terhadap konstruk atau variabel latennya, jika dan standardizes factor loading (SLF) $\geq 0,70$ atau $\geq 0,50$. Berdasarkan nilai nilai standardizes factor loading semua variabel nilainya di atas 0,50 . Hal ini menunjukkan bahwa semua variabel teramati X36 - X40 dapat dimasukkan ke dalam model.

\section{Traits}

Variabel laten Traits terdiri dari lima variabel teramati, seperti yang terlihat dalam gambar dibawah ini:

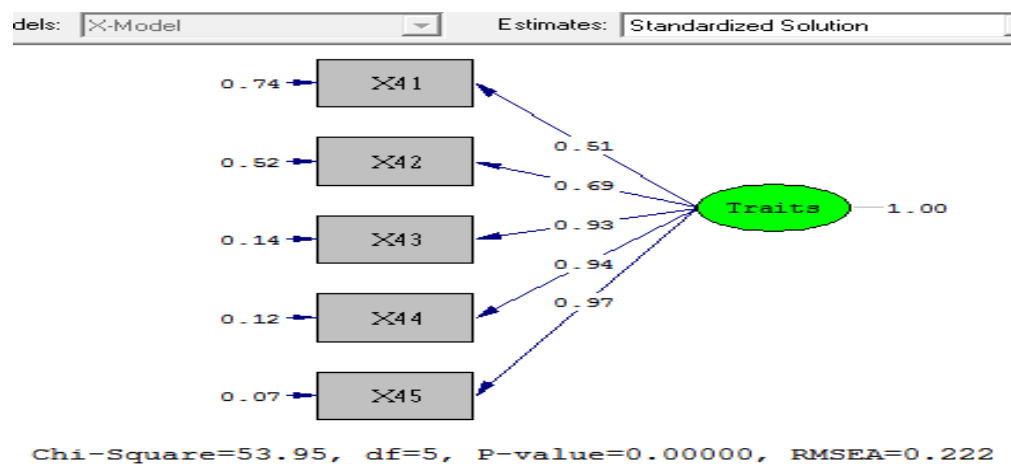

Gambar 11. Traits

Variabel dikatakan mempunyai validitas yang baik terhadap konstruk atau variabel latennya, jika dan standardizes factor loading (SLF) $\geq 0,70$ atau $\geq 0,50$. Berdasarkan nilai nilai standardizes factor loading semua variabel nilainya di atas 0,50 . Hal ini menunjukkan bahwa semua variabel teramati X41 - X45 dapat dimasukkan ke dalam model.

\section{Self Concepts}

Variabel laten Self Conceptsterdiri dari enam variabel teramati, seperti yang terlihat dalam gambar dibawah ini: 


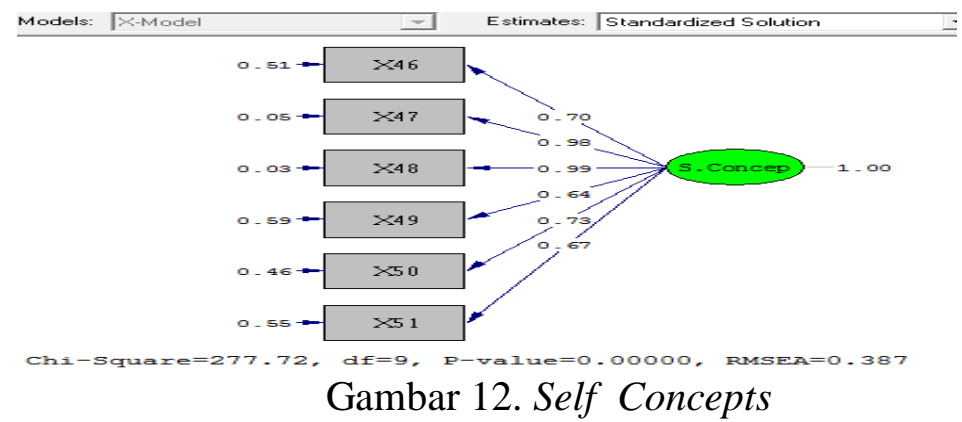

Variabel dikatakan mempunyai validitas yang baik terhadap konstruk atau variabel latennya, jika dan standardizes factor loading (SLF) $\geq 0,70$ atau $\geq 0,50$. Berdasarkan nilai nilai standardizes factor loading semua variabel nilainya di atas 0,50. Hal ini menunjukkan bahwa semua variabel teramati X46 - X51 dapat dimasukkan ke dalam model.

Knowledge Variabel laten knowledge terdiri dari lima variabel teramati, seperti yang terlihat dalam gambar dibawah ini:

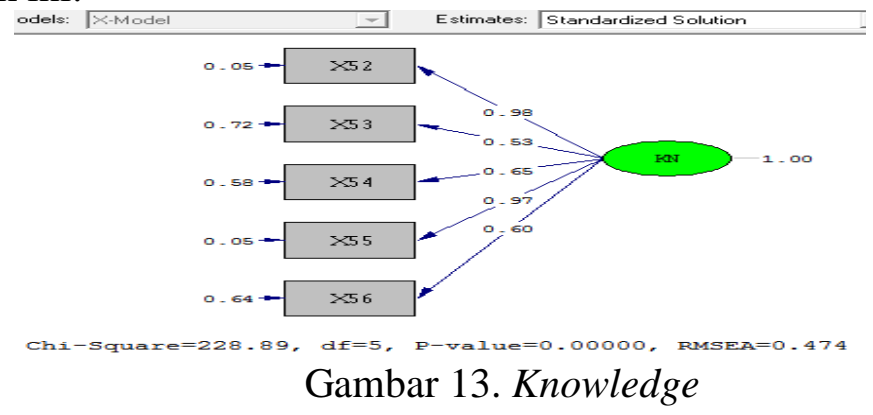

Variabel dikatakan mempunyai validitas yang baik terhadap konstruk atau variabel latennya, jika dan standardizes factor loading (SLF) $\geq 0,70$ atau $\geq 0,50$. Berdasarkan nilai nilai standardizes factor loading semua variabel nilainya di atas 0,50 . Hal ini menunjukkan bahwa semua variabel teramati X52 - X56 dapat dimasukkan ke dalam model.

\section{Skill}

Variabel laten Skill terdiri dari lima variabel teramati, seperti yang terlihat dalam gambar dibawah ini:

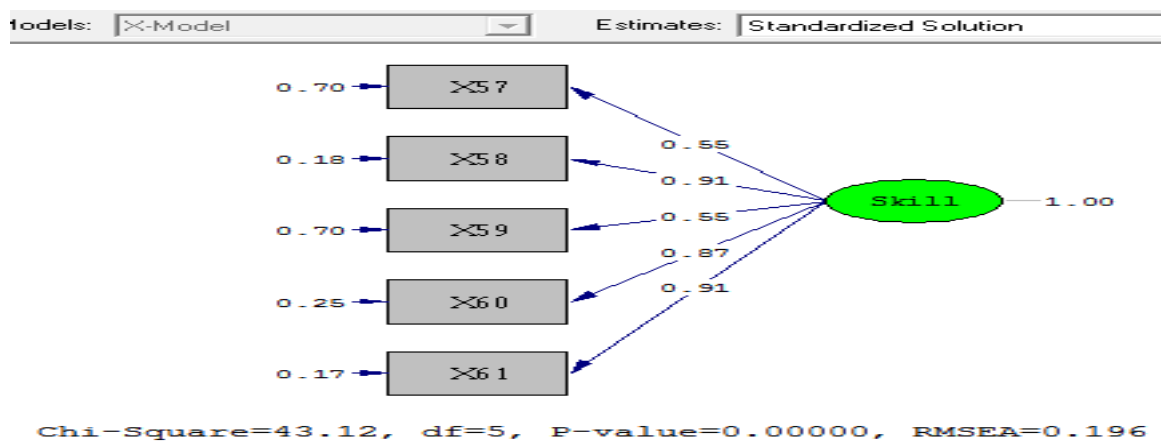

Gambar 14. Skill 
Variabel dikatakan mempunyai validitas yang baik terhadap konstruk atau variabel latenn ya, jika dan standardizes factor loading $(\mathrm{SLF}) \geq 0,70$ atau $\geq 0,50$. Berdasarkan nilai nilai standardizes factor loading semua variabel nilainya di atas 0,50 . Hal ini menunjukkan bahwa semua variabel teramati X57 - X61 dapat dimasukkan ke dalam model.

\section{Kinerja}

Variabel laten Kinerja terdiri dari enam variabel teramati, seperti yang terlihat dalam gambar dibawah ini:

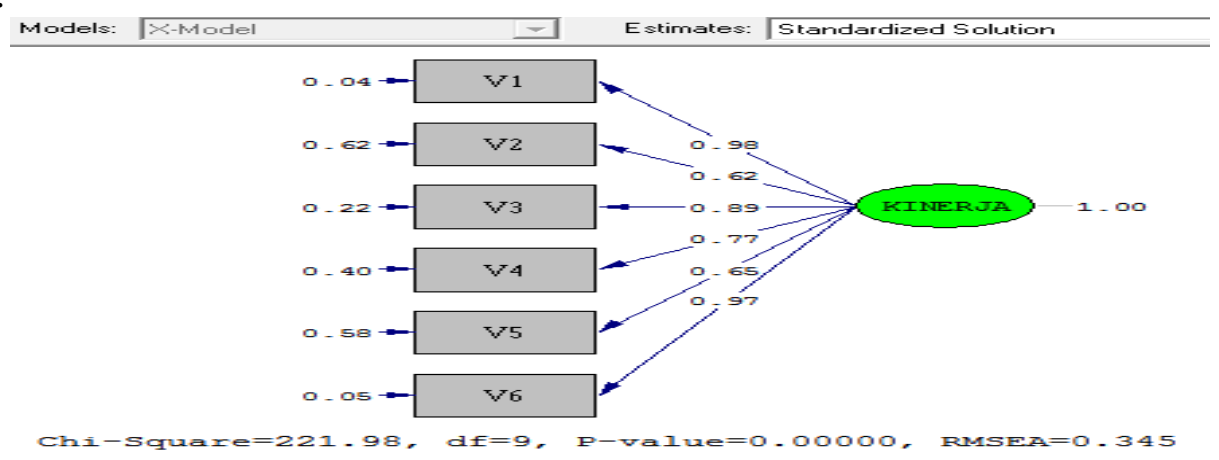

Gambar 15. Kinerja

Variabel dikatakan mempunyai validitas yang baik terhadap konstruk atau variabel latennya, jika dan standardizes factor loading (SLF) $\geq 0,70$ atau $\geq 0,50$. Berdasarkan nilai nilai standardizes factor loading semua variabel nilainya di atas 0,50 . Hal ini menunjukkan bahwa semua variabel teramati V1 - V6 dapat dimasukkan ke dalam model.

\section{Uji Kecocokan Model dan Hipotesis}

Pengujian dilanjutkan dengan mengevaluasi secara umum derajat kecocokan atau Goodnes of Fit(GOF) antara data dengan model. Hair, et al (2005) menyebutkan bahwa GOFI atau GOF indices (ukuran-ukuran GOF) mampu dikelompokkan menjadi 3 bagian yaitu absolute fit measures (ukuran kecocokan absolut), incremental fit measures (ukuran kecocokan inkremental), dan parsimonious fit measures (ukuran kecocokan parsimoni) (Wijanto,2008). Pada prosesnya, penelitian ini hanya akan menekankan pada dua pengukuran yakni absolute fit measures dan incremental fit measures.

Tabel 1.

\begin{tabular}{|l|c|c|}
\hline \multicolumn{1}{|c|}{ Ukuran GOF } & Hasil Estimasi & Hasil Estimasi \\
\hline RMSEA & 0,19 & Marginal Ftt \\
\hline NNFI & 0,95 & Good Fit \\
\hline NFI & 0,95 & Marginal Ftt \\
\hline IFI & 0,96 & Good Fit \\
\hline CFI & 0,96 & Good Fit \\
\hline RFI & 0,94 & \\
\hline
\end{tabular}

Untuk lebih jelasnya akan ditampilkan tigagambar dari LISREL, yaitu gambar estimate, standardized solution dan t values seperti yang terlihat dalam gambar dibawah ini: 


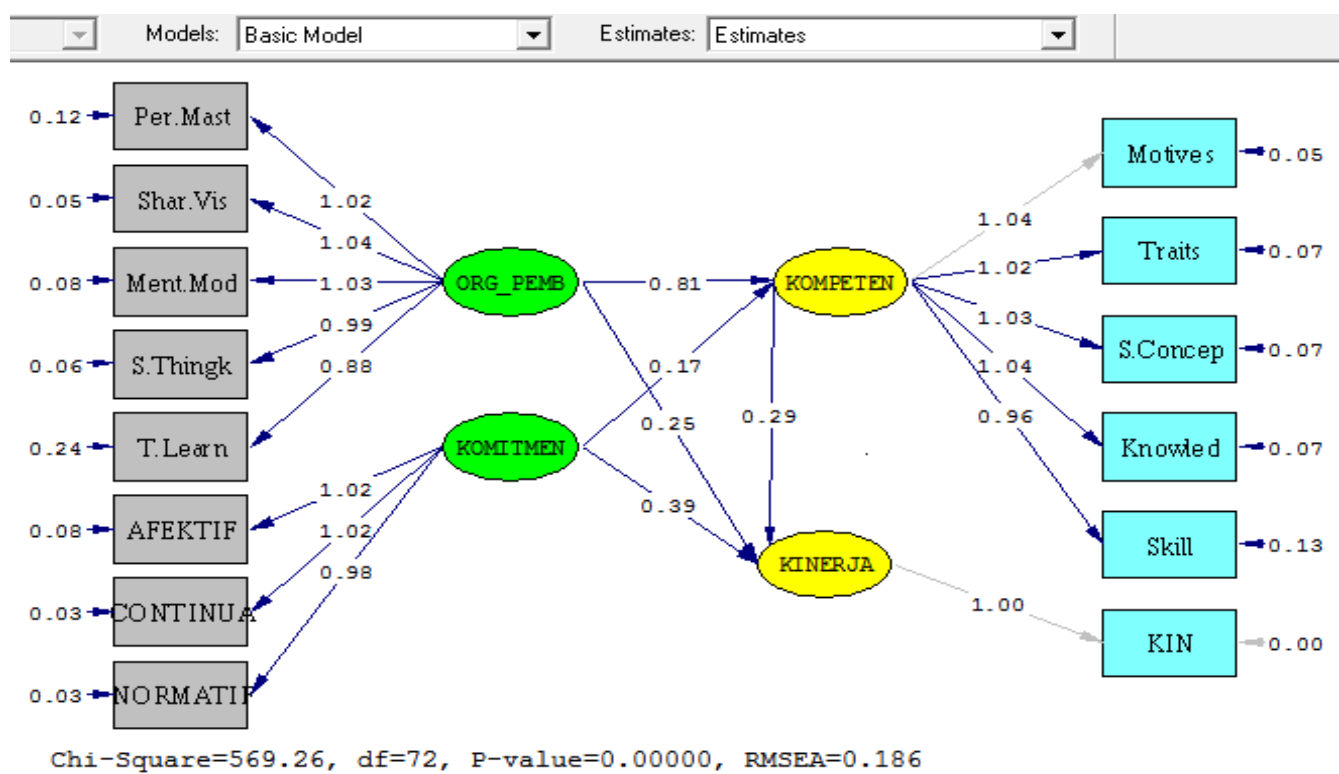

Gambar 16. Model Struktural (Estimate)

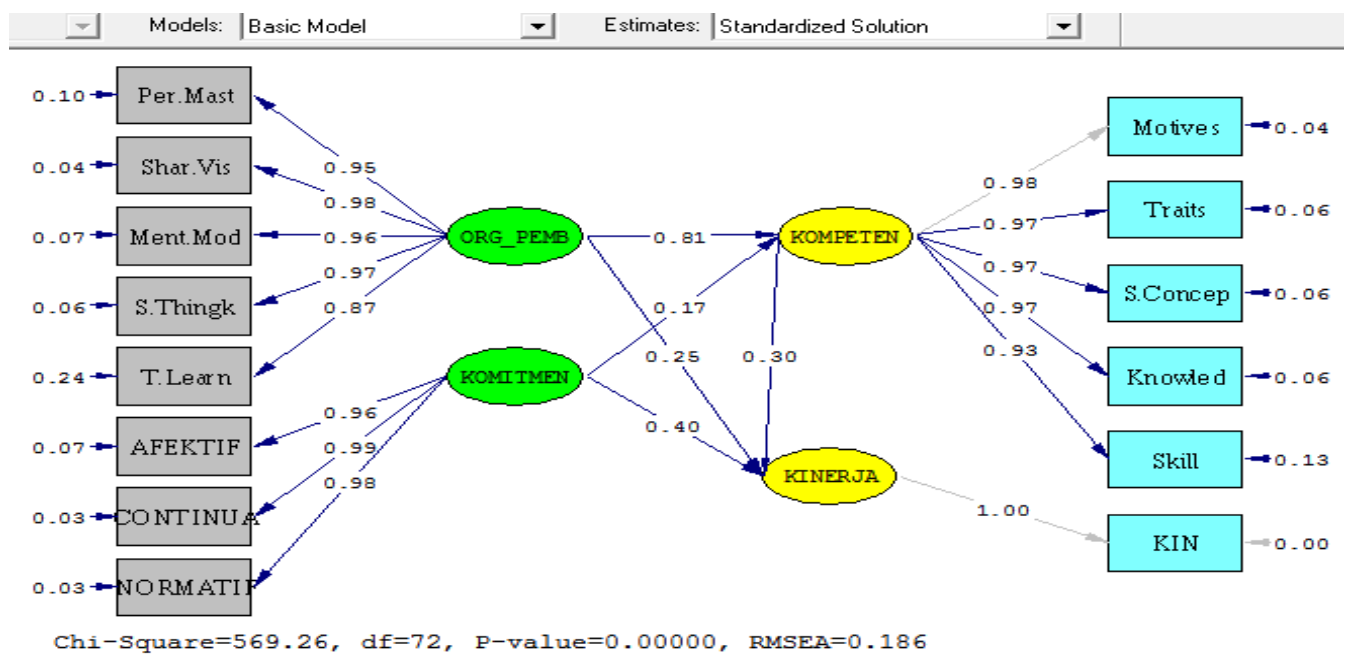

Gambar 17. Model Struktural (Standardized Solution) 


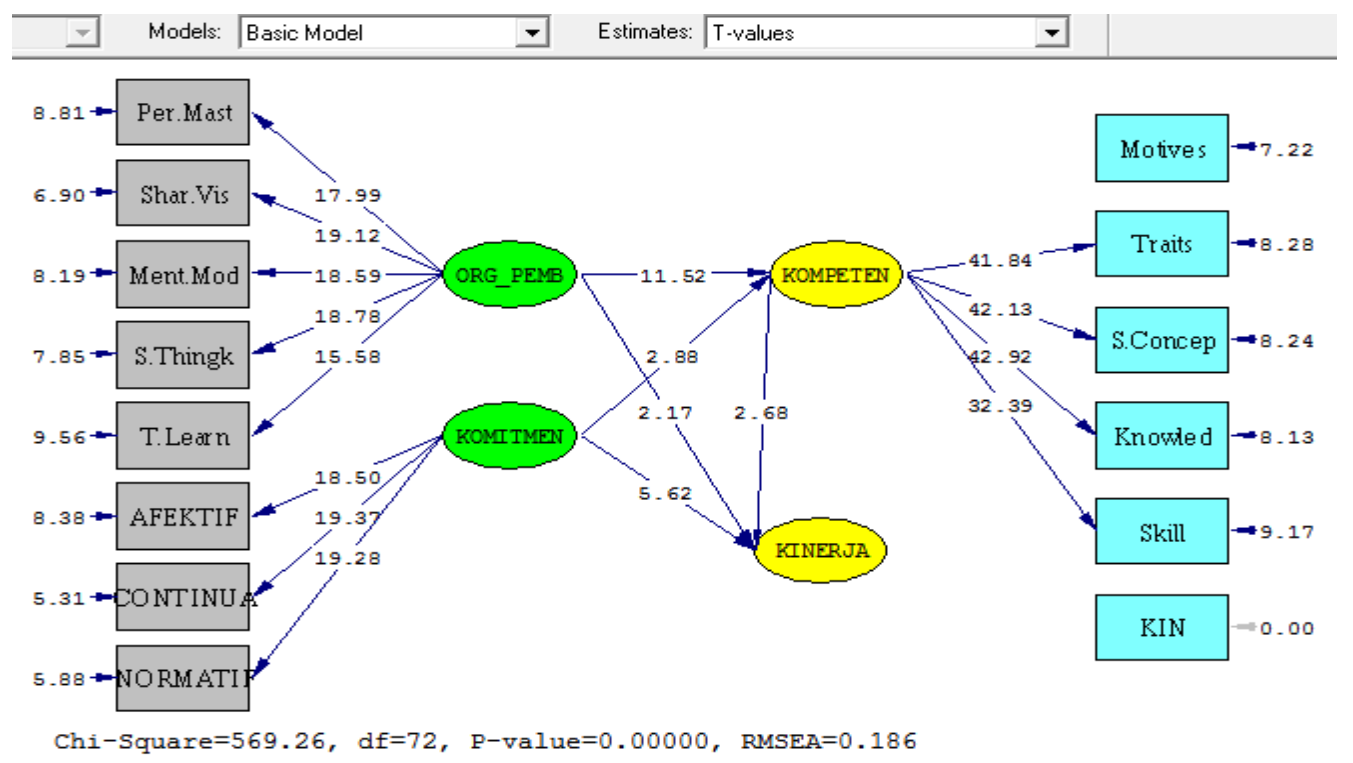

Gambar 18. Model Struktural (T Values)

Gambar model $t$-values menampilkan diagram lintasan model lengkap dengan angka-angka yang menunjukkan nilai-t dari setiap angka hasil estimasi yang terkait. Nilai-t yang $<1,96(\alpha=5 \%)$ ditampilkan dengan warna merah dan menunjukan bahwa angka terkait adalah tidak signifikan atau sama dengan nol.

Selanjutnya berdasarkan gambar diatas terdapat hasil yang mengandung informasi tentang hasil estimasi dari structural equations atau persamaan-persamaan dari model structural. Dimana pada bagian ini berhubungan dengan evaluasi terhadap koefisien-koefisien atau parameter-parameter yang menunjukkan hubungan kausal atau pengaruh satu variabel laten terhadap variabel laten lainnya. Persamaan model struktural yang dihasilkan adalah sebagai berikut:

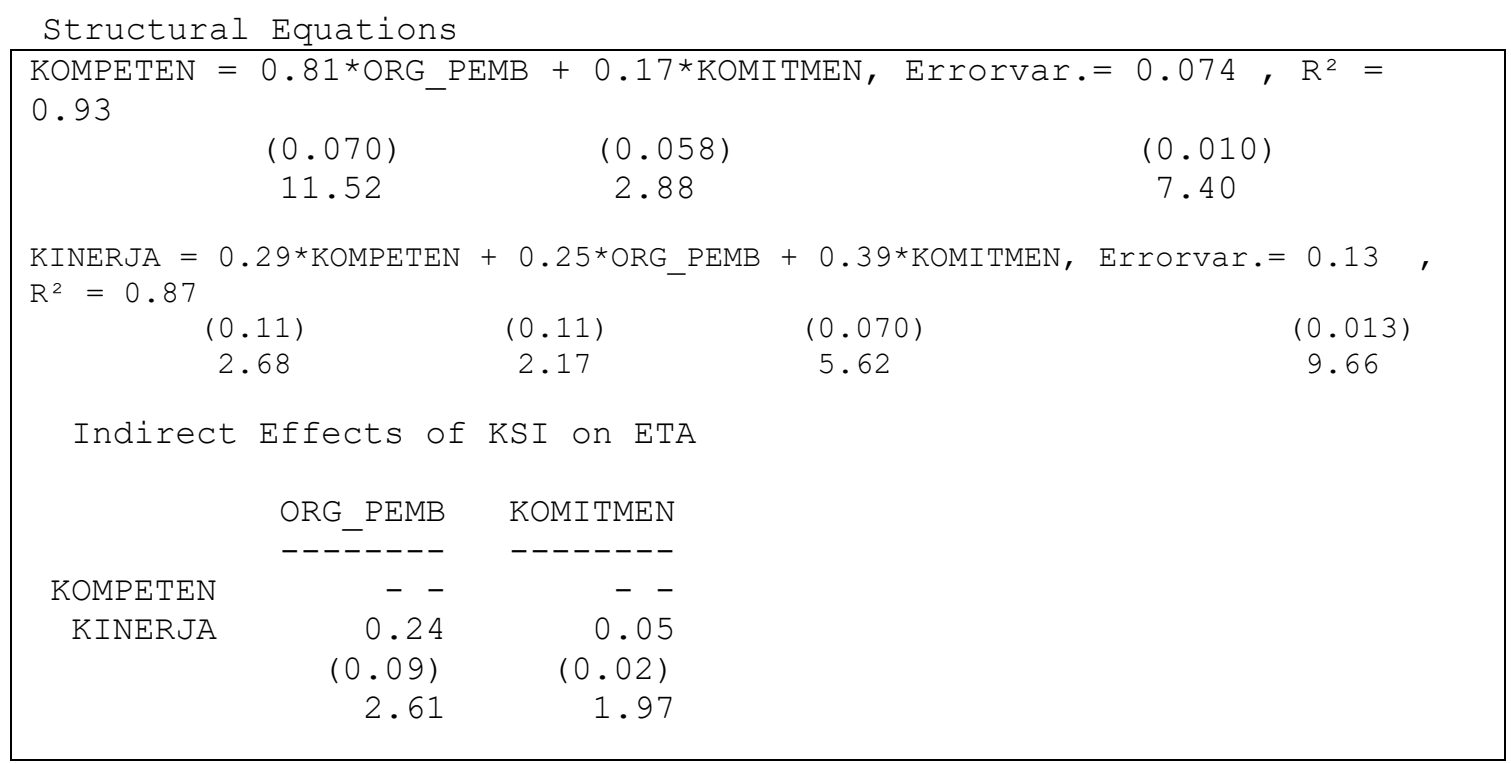

Berdasarkan hasil analisis hipotesis didapatkan hasil: 
Tabel 2.

\begin{tabular}{|l|c|c|c|}
\hline \multicolumn{2}{|c|}{ Path } & Estimasi & $t$-value \\
\hline $\begin{array}{l}\text { Organisasi pembelajaran berpengaruh positif dan signifikan } \\
\text { terhadap kompetensi }\end{array}$ & 0.81 & $11,52>1,96$ \\
\hline
\end{tabular}

Hasil analisis data diketahui bahwa nilai $\mathrm{t}=11,52$. Karena nilai $\mathrm{t}>1,96$ maka $\mathrm{H}_{0}$ ditolak dan $\mathrm{H}_{1}$ diterima, yang berarti organisasi pembelajaran berpengaruh positif dan signifikan terhadap kompetensi. Dengan demikian dapat diambil kesimpulan bahwa organisasi pembelajaran dapat digunakan untuk memprediksi kompetensi.

Berdasarkan hasil analisis hipotesis 2 didapatkan hasil:

Tabel 3.

\begin{tabular}{|lll|c|c|}
\hline & Path & Estimasi & $t$-value \\
\hline $\begin{array}{l}\text { Komitmeni } \\
\text { kompetensi }\end{array}$ & berpengaruh positif dan signifikan terhadap & 0.17 & $2.88>1,96$ \\
\hline
\end{tabular}

Hasil analisis data diketahui bahwa nilai $\mathrm{t}=1.97$. Karena nilai $\mathrm{t}>1,96$ maka $\mathrm{H}_{0}$ ditolak dan $\mathrm{H}_{1}$ diterima, yang berarti komitmen berpengaruh positif dan signifikan terhadap kompetensi. Dengan demikian dapat diambil kesimpulan bahwa komitmen dapat digunakan untuk memprediksi kompetensi.

Berdasarkan hasil analisis hipotesis 3 didapatkan hasil:

Tabel 4.

\begin{tabular}{|l|c|c|c|}
\hline \multicolumn{2}{|c|}{ Path } & Estimasi & $t$-value \\
\hline $\begin{array}{l}\text { Organisasi pembelajaran berpengaruh positif dan } \\
\text { signifikan terhadap kinerja }\end{array}$ & 0.25 & $2.17>1,96$ \\
\hline
\end{tabular}

Hasil analisis data diketahui bahwa nilai $\mathrm{t}=2,17$. Karena nilai $\mathrm{t}>1,96$ maka $\mathrm{H}_{0}$ ditolak dan $\mathrm{H}_{1}$ diterima, yang berarti organisasi pembelajaran berpengaruh positif dan signifikan terhadap kinerja. Dengan demikian dapat diambil kesimpulan bahwa organisasi pembelajaran dapat digunakan untuk memprediksi kinerja.

Berdasarkan hasil analisis hipotesis 4 didapatkan hasil:

Tabel 5.

\begin{tabular}{|c|c|c|}
\hline Path & Estimasi & $t$-value \\
\hline Komitmen berpengaruh positif dan signifikan terhadap kinerja & 0.39 & $5.62>1,96$ \\
\hline
\end{tabular}

Hasil analisis data diketahui bahwa nilai $\mathrm{t}=5$,62. Karena nilai $\mathrm{t}>1,96$ maka $\mathrm{H}_{0}$ ditolak dan $\mathrm{H}_{1}$ diterima, yang berarti komitmen berpengaruh positif dan signifikan terhadap kinerja. Dengan demikian dapat diambil kesimpulan bahwa komitmen dapat digunakan untuk memprediksi kinerja.

Berdasarkan hasil analisis hipotesis 5 didapatkan hasil:

Tabel 6.

\begin{tabular}{|c|c|c|}
\hline Path & Estimasi & t-value \\
\hline Kompetensi berpengaruh positif dan signifikan terhadap kinerja & 0.29 & $2.68>1,96$ \\
\hline
\end{tabular}


Hasil analisis data diketahui bahwa nilai $\mathrm{t}=2$,68. Karena nilai $\mathrm{t}>1,96$ maka $\mathrm{H}_{0}$ ditolak dan $\mathrm{H}_{1}$ diterima, yang berarti kompetensi berpengaruh positif dan signifikan terhadap kinerja. Dengan demikian dapat diambil kesimpulan bahwa kompetensi dapat digunakan untuk memprediksi kinerja.

Organisasi pembelajaran melalui kompetensi berpengaruh positif terhadap kinerja.

Berdasarkan hasil analisis hipotesis 6 didapatkan hasil:

Tabel 7

\begin{tabular}{|c|c|c|}
\hline \multicolumn{1}{|c|}{ Path } & Estimasi & $t$-value \\
\hline $\begin{array}{l}\text { Organisasi pembelajaran melalui kompetensi } \\
\text { berpengaruh positif dan signifikan terhadap kinerja }\end{array}$ & 0.24 & $2.61>1,96$ \\
\hline
\end{tabular}

Hasil analisis data diketahui bahwa nilai $\mathrm{t}=2.31$. Karena nilai $\mathrm{t}>1,96$ maka $\mathrm{H}_{0}$ ditolak dan $\mathrm{H}_{1}$ diterima, yang berarti organisasi pembelajaran melalui kompetensi berpengaruh positif dan signifikan terhadap kinerja.

Berdasarkan hasil analisis hipotesis 7 didapatkan hasil:

Tabel 8.

\begin{tabular}{|l|c|c|}
\hline \multicolumn{1}{|c|}{ Path } & Estimasi & t-value \\
\hline $\begin{array}{l}\text { Komitmen melalui kompetensi berpengaruh positif dan } \\
\text { signifikan terhadap kinerja }\end{array}$ & 0.05 & $1.97>1,96$ \\
\hline
\end{tabular}

Hasil analisis data diketahui bahwa nilai $\mathrm{t}=2.31$. Karena nilai $\mathrm{t}>1,96$ maka $\mathrm{H}_{0}$ ditolak dan $\mathrm{H}_{1}$ diterima, yang berarti komitmen melalui kompetensi berpengaruh positif dan signifikan terhadap kinerja.

\section{Pembahasan}

Berdasarkan hasil yang didapatkan diketahui bahwa beberapa temuan hasil uji hipotesis penelitian adalah sama dengan hipotesis yang diajukan dalam penelitian ini dan juga sesuai dengan beberapa teori yang diacu. Hasil-hasil temuan yang sesuai dengan hipotesis dan teori yang diacu adalah organisasi pembelajaran berpengaruh positif terhadap kompetensi, kompetensi berpengaruh positif terhadap kinerja, serta organisasi pembelajaran dan komitmen melalui kompetensi berpengaruh positif terhadap kinerja.

Organisasi pembelajaran berpengaruh positif dan signifikan terhadap kompetensi, artinya makin baik/ positif organisasi pembelajaran maka makin baik/ positif kompetensi, sebaliknya makin buruk/ negatif organisasi pembelajaran maka makin buruk/ negatif kompetensi. Komitmen berpengaruh positif dan signifikan terhadap kompetensi, artinya makin baik/ positif komitmen maka makin baik/ positif kompetensi, sebaliknya makin buruk/ negatif komitmen maka makin buruk/ negatif kompetensi.

Organisasi pembelajaran berpengaruh positif dan signifikan terhadap kinerja, artinya makin baik/ positif organisasi pembelajaran maka makin baik/ positif kinerja, sebaliknya makin buruk/ negatif organisasi pembelajaran maka makin buruk/ negatif kinerja. Komitmen berpengaruh positif dan signifikan terhadap kinerja, artinya makin baik/ positif komitmen maka makin baik/ positif kinerja, sebaliknya makin buruk/ negatif komitmen maka makin buruk/ negatif kinerja. Kompetensi berpengaruh positif dan signifikan terhadap kinerja, artinya baik/ positif 
kompetensi maka baik/ positif kinerja, sebaliknya makinburuk/ negatifkompetensi maka makin buruk/ negatif kinerja.

Organisasi pembelajaran melalui kompetensi berpengaruh positif terhadap kinerja artinya makin baik/ positif pengaruh organisasi pembelajaran terhadap kompetensi maka akan makin meningkatkan kinerja, sebaliknya makin buruk/ negatif pengaruh organisasi pembelajaran terhadap kompetensi maka akan melemahkan kinerja. Komitmen melalui kompetensi berpengaruh positif terhadap kinerja artinya makin baik/ positif pengaruh komitmen terhadap kompetensi maka akan makin meningkatkan kinerja, sebaliknya makin buruk/ negatif pengaruh komitmen terhadap kompetensi maka akan melemahkan kinerja.

\section{KESIMPULAN DAN SARAN}

\section{Kesimpulan}

Berdasarkan hasil analisis yang telah dilakukan maka diperoleh beberapa kesimpulan penelitian sebagai berikut:

1. Organisasi pembelajaran berpengaruh positif terhadap kompetensi.

2. Komitmen berpengaruh positif terhadap kompetensi.

3. Organisasi pembelajaran berpengaruh positif terhadap kinerja.

4. Komitmen berpengaruh positif terhadap kinerja.

5. Kompetensi berpengaruh positif terhadap kinerja.

6. Organisasi pembelajaran melalui kompetensi berpengaruh positif terhadap kinerja.

7. Komitmen melalui kompetensi berpengaruh positif terhadap kinerja.

\section{Saran}

1. Penelitian sebaiknya dilakukan dengan menggunakan responden dari berbagai bidang profesi yang ada dengan karakteristik yang lebih bervariasi demi meningkatkan tingkat generalisasi serta keragaman pada penelitian.

2. Penelitian hendaknya dilakukan di beberapa kota lainnya, agar memberikan hasil pembahasan yang lebih menyeluruh dan juga memperluas generalisasi hasil penelitian.

3. Penelitian selanjutnya disarankan untuk mengambil variable-variabel lainnya yang secara teori berpengaruh terhadap kompetensi dan kinerja.

4. Penelitian selanjutnya disarankan untuk menambahkan metode kualitatif dengan wawancara pada beberapa responden secara khusus agar dapat diperoleh pemahaman yang lebih mendalam.

\section{REFERENSI}

Arbuck,J.L. (1997). Amos User's Guide Version 3.6.Chicago,IL: SmallWaters Corporation

Baker, W.E. and J.M. Sinkula, 1999, The Synergistic Effect of Market Orientationand Learning Orientation of Organizational Performance, Journal of theAcademy of Marketing Science, Vol. 27, No. 4, pp.411.

Beardwell, Ian \& Holden, Len, 2001. Human Resource Management: A Contemporary Apprach, London: Prentice Hall

Balfour, D.L. dan Bartos W, 1991. Commitment, Performance, and Productivity in As'ad, Muhammad, 1991, Kinerja Sebagai Media Peningkatan Drajad Dalam Konteks Industrialisasi, Geneca, Bandung

Chaston, L. and B. Badger, 1999, Organizational Learning: Research Issues and Application in SME Sector Firms, International Journal of Entrepreneurial

Black, W. C., 1998, Multivariate Data Analysis, 5th Edition, Prentice Hall, Upper Saddle River, USA 
Khandekar, A. and A. Sharma, 2006. Organizational Learning and Performmance:Understanding Indian Scenario in Present Global Context, Education Training, Vol.48 No.8/9, pp.682.

Mowday, R.T., Steers, R.M., \& Porter, L.W. (1984), The measurement of organizational commitment. Journal of Vocational Behavior

Prahalad, C.K. and G. Hamel, 1990. The Core Competence of the Corporation, Harvard Business Review, June, pp.79.

Ruky, S. Achmad, System Manajemen Kinerja : Panduan Praktis Untuk Merancang dan Meraih Kinerja Prima, Gramedia, Jakarta, 2001.

Miarso, Yusufhadi, 2002. Peran Teknologi Pembelajaran Dalam Organisasi Belajar, Makalah yang disampaikan pada Seminar Nasional Teknologi Pembelajaran, Jakarta

Oliver, C., 1997. Sustainable Competitive Advantage: Combining Institutional and Resources-based View, Strategic Management Journal, Vol.18, No.9, pp.697.

Senge, P., Ross, R., et.al. (1999). The Dance of Change: The Challenges of Sustaining Momentum in a Learning Organization. New York : Doubleday \& Co.

Senge, P.M., 1990. The Leader's New Work: Building Learning Organizations, Sloan Management Review, Fall 32 (1), pp.7-23.

Swanson, Richard A \& Holton, Elwood, F, 2001, Foundation of Human Resource Development, San Fransisco: Berrett-Koehler Publisher, Inc.,

Wang, Y. and H. Lo, 2003. Customer-focused Performance and the Dynamic Model for Competences Building and Leveraging: A Resource-based View, Journal of Management Development, Vol.22, No.6, pp.483.

Whitmore, J. (2002) Coaching for Performance, Nicholas Brealey Publishing, London 